\title{
Sosyal Hizmet Uzmanlarının Çalışma Yaşamlarında Karşılaştıkları Sorunlar: Burdur İli Örneği ${ }^{1}$
}

\author{
Bilgesu ÇÜM *, Cemile Zehra KÖROĞLU**
}

ÖZ

$\mathrm{Bu}$ araştırmada sosyal hizmet uzmanlarının çalışma yaşamlarında karşılaştıkları sorunların belirlenmesi ve elde edilen bulguların incelenmesi amaçlanmıştır. Araştırmanın sonuçları, sosyal hizmet uzmanlarının sorunlarına 1şık tutabileceği ve bu sorunlara çözüm üretilebilmesi noktasında duyarlılığı artırabileceği için önemli görülmektedir. Araştırma, nitel yöntem kullanılarak Burdur ilinde çalışmakta olan tüm sosyal hizmet uzmanları ile derinlemesine görüşülerek yürütülmüştür. Elde edilen veriler içerik analizine tabi tutularak betimsel olarak incelenmiştir. Analiz için NVIVO paket programı kullanılmıştır. Yapılan analizler sonucunda, sosyal hizmet uzmanlarının çalışma yaşamında en çok karşılaştıkları sorunlar; mevzuattan kaynaklı sorunlar, mobbinge maruz kalmak, aşırı evrak yükü, sosyal hizmet uzmanlarına gerekli önem ve değerin verilmemesi, kurumlardaki fiziki koşulların uygunsuzluğu, iş yoğunluğu ve maaşların yetersizliği olarak belirlenmiştir.

Anahtar Kelimeler: Sosyal Hizmet Uzmanı, Sosyal Hizmet Uzmanlarının Sorunları, NVIVO

JEL Sinıflandırması: J81, Z22

\section{Problems of Social Workers Encountered in Working Lives: Example of Burdur Province}

\begin{abstract}
In this study, it is aimed to determine the problems encountered by social workers in their working lives and it is aimed to examine the findings. The results of the study are considered as important because they will shed light on the problems of social workers and increase the sensitivity to these problems in the point of finding solutions. The research was carried out in depth with all social workers working in Burdur province by using qualitative method. The data were analyzed being subject to content analysis descriptively. NVIVO package program was used for analysis. Result of the analyses were specified as the most common problems encountered by social workers in working lives such problems as arising from legislation, exposure to mobbing, overload of documents, lack of importance and value given to social workers, non-compliance of physical conditions in institutions, job density and inadequacy of salaries.
\end{abstract}

Keywords: Social Worker, Problems of Social Workers, NVIVO

JEL Classification: J81, Z22

Geliş Tarihi / Received: 21.07.2020 Kabul Tarihi / Accepted: 17.12.2020 Doi:10.17541/optimum772700

\footnotetext{
1 Bu makale, Uşak Üniversitesi Sosyal Bilimler Enstitüsü Sosyal Hizmet Anabilim Dalında sunulan 'Sosyal Çalışmacıların Motivasyon Kaynaklarının ve İş Yaşamlarında Karşılaştıkları Sorunların İncelenmesi’ adlı Yüksek Lisans Tezinden geliştirilmiştir.

* Araş. Gör., Uşak Üniversitesi, İktisadi ve İdari Bilimler Fakültesi, Sosyal Hizmet Bölümü, bilgesu.cum@usak.edu.tr, ORCID: 0000-0001-7489-1887.

** Doç. Dr., Uşak Üniversitesi, İktisadi ve İdari Bilimler Fakültesi, Sosyal Hizmet Bölümü, cemile.koroglu@usak.edu.tr, ORCID:0000-0002-9043-1773.
} 


\section{GİRIŞ}

Sosyal hizmet, sosyal işlevselliği artırmak, bireylerin sorun çözme, sorunlarla baş etme ve gelişme kapasitelerini arttırmak, sistemlerin etkili ve insancıl olarak işlev görmesini sağlamak, özlenen amaçlara uygun toplumsal koşulları yaratmak üzere bireylere, gruplara, ailelere ve topluluklara yardımı kapsayan mesleki bir çalışmadır (Zastrow, 2016). Sosyal hizmet, sosyal değişim ve gelişim amacı güden, baskı altında olan bireylerin özgürleştirilmesi ve güçlendirilmesine katkı sağlayan, ırk, sınıf, dil, din, cinsiyet, engellilik, kültür ve cinsel yönelim bazında meydana gelen baskı ve ayrımcılığın yapısal kaynakları üzerine eleştirel bilinç ve eylem stratejileri geliştiren bir disiplin ve uygulama mesleğidir (Duyan, 2019).

Bir işin meslek olarak tanımlanabilmesi için birtakım unsurlar gereklidir. Bu unsurlar amaç, yöntem, bilgi temeli, eğitim, uygulama alanı ve uygulayıcılar kadrosu, mesleki değerler toplumun kabulüdür (Kongar, 1972). Sosyal hizmeti meslek yapan, mesleğin uygulayıcıları ise sosyal hizmet uzmanlarıdır. Bu kapsamda konunun daha iyi anlaşılması açısından sosyal hizmet uzmanı kavramına değinmek yerinde olacaktır.

Sosyal hizmet uzmanları, insanın önemli ve değerli bir varlık olduğunu kabul ederek yaşadığ 1 problemleri kendi kendine çözmeyi başaramayan insan ve insani durumlar üzerine çalışan meslek elemanlarıdır. Bu insanlar, engelli, yoksul, hükümlü, ihmal veya istismara uğramış vb. durumda olan kişilerdir. Bu durumdaki bireylerle çalışmak, sosyal hizmet mesleğine özgü yöntem ve teknikleri içeren belli bir eğitim almayı gerektirir. Bu bağlamda sosyal hizmet uzmanları, dezavantajlı konumda bulunan insan ve onun çevresiyle etkileşimini göz önüne alarak çalışabilmek için bilgi, değer ve becerilerle donatılmış kişilerdir. Fakat çeşitli mesleklerin uygulayıcılarının meslek yaşamlarında karşılaştığı gibi sosyal hizmet uzmanları da birtakım problemlerle karşı karşıya kalırlar. Sosyal hizmet uzmanları, dezavantajlı konumda bulunan birey ve gruplara profesyonel yardım sağlamak, onları topluma kazandırmak gibi önemli amaçlara hizmet eden ve faydacı amaçları olan meslek elemanları olmalarına rağmen, yaşanan problemler sunulan hizmetlerin etkili ve verimli olmasını engelleyebilecek, bu kesimlerin hizmetten fayda sağlama düzeylerinin azalmasına neden olabilecektir. Bu açıdan sosyal hizmet uzmanlarının mesleki yaşamlarında karşı karşıya kaldıkları problemlerin tespit edilmesi, bu problemlere yönelik çözüm üretilebilmesi ve sunulan hizmetlerde en üst düzeyde fayda sağlanabilmesi açısından oldukça önemli görülmektedir. Bu bağlamda, bu çalışma, sosyal hizmet uzmanlarının mesleki yaşamlarında karşılaştıkları sorunların ortaya koyulmasını amaçlamaktadır. $\mathrm{Bu}$ amaç doğrultusunda, sosyal hizmet mesleğinin herhangi bir alanında çalışan kadın sosyal hizmet uzmanlarının dile getirdikleri sorunlar nelerdir? (1) Sosyal hizmet mesleğinin herhangi bir alanında çalışan erkek sosyal hizmet uzmanlarının dile getirdikleri sorunlar nelerdir? (2) Çalışma hayatında yaşadıkları sorunların sosyal hizmet uzmanlarının motivasyonları üzerindeki etkileri nelerdir? (3) sorularına yanıt aranmıştır. Diğer yandan araştırma nitel araştırma düzeyinde bir durum çalışmasıdır. Elde dilen veriler tümevarımcı analiz yolu ile içerik analizine tabi tutularak betimsel olarak incelenmiştir.

\section{SOSYAL HİZMET EĞİTIMİ VE YETERLILLIKLERİ}

Sosyal hizmet uzmanları, nerede çalışırsa çalışsınlar aile içi şiddet deneyimleri, gençlik sorunları, gençlerin madde kullanımına yönelimleri, gençlerin ebeveynlerine ve çevrelerine karşı duygusal ve sosyal tepkileri, yakın bir kişinin kaybedilmesi sonucu oluşan yas süreçleri, cinsel ihmal ve istismar gibi karmaşı yaşam durumları ile ilgilenirler (Payne, 2008: 15). Diğer yandan sosyal hizmet uzmanları, birey, aile ve grup temelli müdahalelerin yanı sira makro düzeyde müdahale içerisinde de bulunurlar. Makro düzeyde müdahaleler, kanunların, sosyal politikaların, kurumların ve sosyal sistemlerin geliştirilmesi, bireyler için firsatların artırılması, ayrımcılığın önlenmesi için düzenlenen yerel ve toplumsal organizasyonlara yardım edilmesi gibi topluluk 
çalışmalarını kapsamaktadır (Sheafor ve Horejsi, 2014: 26). Tüm bu müdahalelerin etkili bir şekilde yapılabilmesi, birey, grup ve toplum üzerinde herhangi bir hasar meydana gelmemesi açısından iyi bir sosyal hizmet eğitimi gerekmektedir.

Her ne kadar Türkiye'de sosyal hizmet mesleği ve eğitimi yeni olsa da ABD ve İngiltere gibi gelişmiş Batı ülkelerinde sosyal hizmet eğitiminin 1800'lü yılların son çeyreğinde başladığg görülmektedir. İlk kez birtakım bilgi, değer ve becerilerle donatılmış sosyal hizmet uzmanı yetiştirmek üzere, 1903'te Londra Üniversitesi Sosyoloji Bölümü'nde sosyal çalışma eğitimi başlamıştır. Bundan sonra sosyal çalı̧̧ma eğitimi Amerika'da başlamıştır. 1899 yılında Amsterdam'da 'Institute for Social Work Training' adlı ilk sosyal hizmet okulu açılmıştır. Bundan sonraki yıllarda, diğer ülkelerde profesyonel olarak sosyal hizmet eğitimi vermek amaciyla okullar açılmaya başlamıştır. 1914'de Kanada'da bulunan Toronto Üniversitesinde sosyal hizmet eğitimi sunulmuştur. 1920'de Latin Amerika ülkesi olan Şili'de açılan sosyal hizmet okulu mesleki eğitim vermek üzere faaliyete geçmiştir. 1924'te Güney Afrika'da, 1936'da ise Mısır'da diğer sosyal hizmet okulları açılmıştır. Asya kıtasında sosyal hizmet eğitiminin öncülüğünü 1936 y1lında Hindistan'da kurulan Tata Sosyal Bilimler Enstitüsü yapmıştır. İlerleyen yıllarda sosyal hizmet eğitimi veren kurumlar yaygınlık göstermeye devam etmiştir (Hokenstad, 2012: 166; Kut, 1988: 36).

Okullaşma ile birlikte, Uluslararası Sosyal Hizmet Okulları Derneği [International Association of Schools of Social Work (IASSW)], Uluslararas1 Sosyal Hizmet Uzmanları Federasyonu [International Federation of Social Workers (IFSW)] ve Birleşmiş Milletler (BM) gibi uluslararası örgütler de sosyal hizmet eğitimini ve kaliteli eğitim programlarının gelişimini desteklemiştir. Bu gelişmelerle birlikte sosyal hizmet Amerika Birleşik Devletleri, İngiltere, Kanada, Hindistan ve diğer pek çok ülkede tanınan dünya çapında bir meslek haline gelmiştir.

Tarihsel süreçte profesyonel anlamda sosyal hizmet eğitimi 19. yüzyılın sonlarında başlamasına karşın, Türkiye'de ancak 1961 yılında Sağlık ve Sosyal Yardım Bakanlığı bünyesinde Sosyal Hizmetler Enstitüsüne bağlı olarak açılan Sosyal Hizmetler Akademisi ile başlamıştır. Daha sonra 1967 yılında Hacettepe Üniversitesinin İktisadi ve İdari Bilimler Fakültesine bağlı olarak sosyal çalışma bölümü açılmıştır (Yiğit, 2017: 156). 1982 y1lında bu iki okul Yüksek Öğretim Kanunu ile Hacettepe Üniversitesi bünyesinde birleştirilerek Sosyal Hizmetler Yüksekokulu adıyla eğitime devam etmiştir. 2006 yılında Sosyal Hizmetler Yüksekokulu Hacettepe Üniversitesi İktisadi ve İdari Bilimler Fakültesi bünyesinde Sosyal Hizmet Bölümü olarak yeniden yapılandırılmıştır (Iş̧khan vd., 2016: 3). 2002 yılında Başkent Üniversitesi bünyesinde Sosyal Hizmet Bölümü açılmış, böylelikle bölüm sayısı ikiye çıkmıştır. 2006 yılından itibaren ise bölüm sayıları her yıl artış göstermiştir. Türkiye'de sosyal hizmet eğitiminin okullaşma bazında başlangıcından 2006 yılına kadar olan dönemde gelişemediği, 2006 yılı ve sonrası dönemde ise kontrolsüz bir büyümenin hâkim olduğu görülmektedir (Alptekin, 2016: 20).

Sosyal hizmet eğitimiyle sosyal hizmet uzmanlarına birtakım bilgi, beceri ve yetkinlikler kazandırmak hedeflenmektedir. Bu bilgiler, dezavantajlı gruplar hakkında bilgi, bireysel ve toplumsal problemler hakkında bilgi, insan davranışları hakkında bilgi, sistem teorisi, benlik teorisi ve diğer teoriler, insanın gelişim evreleri, inançlar, din ve tinsellik hakkında bilgi, etkili iletişim bilgisi, sosyal politika bilgisi, mevzuat bilgisi, sosyal hizmet uygulaması, bireye, gruba ve topluma yönelik müdahale yöntemleri, dezavantajlı grupları topluma kazandırma yolları hakkında bilgi, vakaların zamanında ve etkili çözülebilmesi için süreç yönetimi ve sistematik uygulama hakkında bilgi şeklinde sıralanabilir (Augustine ve Gentle Genitty, 2013: 11). Sosyal hizmet uzmanlarının bilmesi gerekenlerin ne olduğuna dair bir sınırlama getirmek doğru olmayacaktır. Bunların bir belirleyicisi yoktur, hem mesleki hem de kişisel olarak öğrenmeye ve gelişmeye sürekli açık olmak gerekmektedir. 
Sosyal çalışmanın tanıtımı ile ilgili çalı̧̧masında Engelbrech (1999: 5) sosyal hizmet uzmanlarının mesleği icra edebilmesi için taşıması gereken özellikleri; insan sevgisi, duyguların yönetimi, öz farkındalık, kişiler arası iletişim yeteneği, analitik düşünebilme yeteneği, empatik anlayış, ögrenmeye istekli olma, kendine güven ve kararlılık, azimli, sorumluluk sahibi, iyimser, hevesli, sağduyulu, enerjik, doğal ve içten olma, iyi niyet, samimiyet, yaratıcılık, şartlara uyabilme, liderlik potansiyeline sahip olmak şeklinde ortaya koymuştur. Sosyal hizmet uzmanlarından beklenilen diğer bir özellik de bireyciliğe dayanan ideolojileri eleştirmeleri, gerçekçi ve idealist kişiler olmalarıdır (Doel, 2012: 23; Humphrey, 2011: 35 ). Bu tür özellikler sosyal hizmet uzmanlarını motive eder, kendi hayal kırıklıkları ile baş edebilmelerini sağlar, hizmetlerin etkili bir biçimde sunulmasına yardımcı olarak ilerleme, gelişme ve değişmeyi kolaylaştırır, problemlerin firsata çevrilmesini olanaklı kılar. Ayrıca sosyal hizmet uzmanlarının müracaatçıları ile iletişimlerinin daha kolay kurulmasına yardımcı olur, müracaatçılar değişmeye ve gelişmeye daha fazla istekli olurlar.

Kısacası mesleği icra ederken birtakım özellik, beceri ve bilgiye sahip olması gereken sosyal hizmet uzmanları, eğitim sürecinden başlayarak kendilerini geliştirmekten, istihdam edildikleri alanlarda mesleki bilgilerini uygulamaya dönüştürmekten, toplumun ve insanlığın yararına mesleki etkinlikler üretmekten sorumludurlar. Ayrıca toplum içinde ve kurumsal organizasyonlarda mesleki yapıları geliştirmek ve bu yapıların kurumsallaşmasını sağlamak, mesleki rol ve sorumluluklarını yerine getirerek mesleğin gelişmesine, yaygınlaşmasına ve tanınmasına katkıda bulunmak sosyal hizmet uzmanlarının vazgeçilmez görevlerindendir (Cılga, 2002, akt. Koç, 2015: 15).

\section{SOSYAL HIZMET UZMANLARININ TEMEL MESLEKİ SORUNLARI}

Sosyal hizmet uzmanlarının mesleki yaşamlarında karşılaşmış olduğu birtakım sorunlar mevcuttur. Bireylerin sosyal hizmet uzmanlarının kim olduğu ve ne yaptığı ile ilgili fazla bilgisinin olmaması, mesleğin toplum bazındaki imajının düşük olduğunu göstermekte, bu durum sosyal hizmet uzmanlarının mesleğe olan bağlılığını azaltabilmektedir. Öte yandan bazı sosyal hizmet uzmanları, yaptıkları işin gittikçe prosedürleşen yapısından ve istedikleri kadar koruyucu-önleyici çalışmalara zaman ayıramadıklarından yakınmaktadır. Yapılan bazı araştırmalar, sosyal hizmet uzmanlarının verdikleri mesleki hizmetlerden giderek koparak rutin işlemler içerisinde boğulmakta olduğunu ve meslekteki profesyonelliğin yerini bürokrasiye bıraktığını ortaya koymuştur (Thompson, 2013: 237).

Ayrıca zamanın kısıtlı olması nedeniyle bireylerin problemlerinin kaynağına inilemeden ve bireylerle yeterli görüşme yapılamadan karar alınmak zorunda kalınması, mesleki müdahalelerde idari kontrolün çok fazla olması, iş yükünün fazla olması, cinsiyet farklılığına dayalı sorunlar sosyal hizmet uzmanlarının meslek hayatlarında karşılaştıkları diğer sorunlardır. Türkiye'deki sosyal hizmet uzmanlarının bunlara ek olarak aydınlatılması gereken pek çok sorunu mevcuttur. Bu bağlamda, sosyal hizmet uzmanlarının çalışma yaşamında karşılaştıkları sorunları tespit edebilmek ve bu sorunlara çözüm üretebilmek, bu konu üzerinde çalışma yapma ihtiyacını doğurmaktadır. Bu nedenle, bu araştırma sosyal hizmet uzmanlarının, çalışma yaşamında karşılaşmış oldukları sorunlarını, bu sorunlara ilişkin görüşlerini ortaya koymak amacıyla yapılmıştır. 


\section{YÖNTEM}

\subsection{Araştırmanın Modeli}

$\mathrm{Bu}$ araştırmada sosyal hizmet uzmanlarının çalışma yaşamlarında karşılaştıkları sorunların derinlemesine incelenmesi amaçlanmaktadır. Bu bağlamda bu araştırma nitel araştırma düzeyinde bir durum çalışmasıdır.

\section{2. Çalışma Grubu}

Araştırmanın çalışma grubunu Burdur ilinde ve ilçelerinde sosyal hizmet mesleğini icra eden sosyal hizmet uzmanları oluşturmaktadır. Araştırma kapsamında Burdur il ve ilçelerindeki tüm sosyal hizmet uzmanlarına ulaşılmış ve toplam 33 sosyal hizmet uzmanı ile görüşülmüştür. Araştırma kapsamında Burdur ilinin seçilmesinin nedeni, Burdur ilinde daha önce buna benzer bir çalışmanın yapılmamış olması, buna bağlı olarak araştırma kapsamında farklı sonuçların elde edileceğinin düşünülmesidir. Araştırmanın örneklemine ilişkin bilgiler tablo 1 ve tablo 2'de sunulmuştur.

Tablo 1: Cinsiyete İliş̧kin Dağılım

\begin{tabular}{cc}
\hline Cinsiyet & Frekans \\
\hline Kadın & 17 \\
\hline Erkek & 16 \\
\hline Toplam & 33 \\
\hline
\end{tabular}

Tablo 1'de görüldüğü üzere araştırmanın örneklemini 33 sosyal hizmet uzmanı oluşturmaktadır. Araştırmaya katılan sosyal hizmet uzmanlarının 17'si kadın, 16'sı erkektir.

Tablo 2: Araştırma Örneklemine İlişkin Bilgiler

\begin{tabular}{lcc}
\hline Kurumlar & Kadın & Erkek \\
\hline Burdur Aile, Çalışma ve Sosyal Hizmetler İl Müdürlüğü & 11 & 10 \\
\hline Burdur Devlet Hastanesi & 1 & 2 \\
\hline Burdur Halk Sağlı̆̆ı Müdürlüğü & & 1 \\
\hline Burdur E Tipi Kapalı Ceza İnfaz Kurumu (Cezaevi) & 3 & 2 \\
\hline Bucak Sosyal Hizmet Merkezi & 2 & 1 \\
\hline Bucak Devlet Hastanesi & & 16 \\
\hline Bucak İsmail Şerife Sarı Bakım ve Rehabilitasyon Merkezi & 17 & \\
\hline Gölhisar Sosyal Hizmet Merkezi & & \\
\hline Toplam & & \\
\hline
\end{tabular}

\subsection{Araştırma Etiği}

$\mathrm{Bu}$ araştırma "Sosyal Çalışmacıların Motivasyon Kaynaklarının ve İş Yaşamlarında Karşılaştıkları Sorunların İncelenmesi" adlı yüksek lisans tez çalışmasından üretildiği için, çalışma kapsamında daha önce tez için alınan etik kurul izni kullanılmıştır. Etik kurul izni için 
Uşak Üniversitesinin ilgili etik kurul birimine başvurulmuş ve Bilimsel Araştırma ve Yayın Etiği Yönergesi gereğince Uşak Üniversitesi Sosyal ve Beşerî Bilimler Bilimsel Araştırma ve Yayın Etiği Kurulunun 10.01.2019 tarih ve 2019-01 sayılı kararı ile araştırma kapsamında uygulanacak yöntemlerin etik açıdan uygun olduğuna karar verilmiştir.

Ayrıca, veriler toplanırken gizlilik ve gönüllülük esas alınmış, katılımcılarla birbirlerinin anlattıklarını duyamayacakları şekilde teker teker görüşülmüş, bireylerin mahremiyetlerinin korunması ilkesi gereği hiçbir şekilde katılımcıların kim olduğunu belli edecek bilgilere yer verilmemiş̧ir. Yine müracaatçıların mahremiyetlerinin korunması açısından bir sorun alanı herhangi bir vaka örneği üzerinden ele alınmamıştır.

\subsection{Veri Toplama Araçları}

$\mathrm{Bu}$ araştırmada sosyal hizmet uzmanlarının çalışma yaşamında karşılaştıkları sorunların neler olduğunun ortaya konulabilmesi amaciyla, literatür ve alanda uzman kişilerin görüşleri dikkate alınarak yarı yapılandırılmış görüşme formu oluşturulmuş ve nitel araştırmanın veri toplama yöntemi olan bireysel görüşme tekniğinden faydalanılmıştır. Yarı yapılandırılmış görüşme formunda demografik bilgilerin de elde edilebileceği 12 soru yer almaktadır.

Uygulama esnasında katılımcılar görüşmenin araştırma kapsamında yapıldı̆̆ı, gizliliğin ve gönüllülüğün esas olduğu ve katılmak istemediklerinde belirtmelerinin yeterli olduğu konusunda bilgilendirilmiştir. Daha sonra sosyal hizmet uzmanlarının yarı yapılandırılmış görüşme formunda yer olan sorulara ayrıntılı cevaplar verebilmeleri için her biriyle ortalama 15 'er dakikalık görüşme yapılmıştır. Görüşmeler sosyal hizmet uzmanlarının kendilerini rahat ve doğru bir şekilde ifade edebilmesi için her katılımcı ile ayrı ayrı görüşme gerçekleştirilmiştir.

\subsection{Verilerin Analizi}

$\mathrm{Bu}$ araştırmada elde dilen veriler tümevarımcı analiz yolu ile içerik analizine tabi tutularak betimsel olarak incelenmiştir. Araştırmada toplanan veriler detaylı bir şekilde incelenmiş ve araştırmanın amaçları çerçevesinde önemli olan kısımlar saptanmıştır. Verilerin detaylı bir şekilde incelenmesi sonucu tümevarımcı analiz yoluyla belirli kodlar ortaya konulmuş ve verilerin işlenmesi noktasında öneme sahip olan bir kod listesi oluşturulmuştur. Kod listesi sosyal hizmet uzmanlarının çalışma yaşamında karşılaştıkları sorunları ortaya koymak amacıyla düzenlenmiştir.

Analiz için NVIVO paket programı kullanılmış ve oluşturulan kodlar ile katılımcıların ifadelerinin yer aldığı görüş̧me formları programa aktarılmıştır. Sosyal hizmet uzmanlarının çalışma yaşamında karşılaştıkları sorunlara yönelik ifadeleri, oluşturulan kodların içerisine yerleştirilmiştir. $\mathrm{Bu}$ yerleştirme işleminde katılımcıların ifadeleri ile oluşturulan kodların anlamsal olarak birbirine benzerliği dikkate alınmıştır. Her kodun kaç defa ifade edildiği sayısallaştırılarak frekanslarla gösterilmiştir. Daha sonra kodlar doğrudan alıntılarla desteklenmiştir. Sosyal hizmet uzmanlarının verdiği yanıtların gizliliğini koruyabilmek için erkek sosyal hizmet uzmanlarına "ES', kadın sosyal hizmet uzmanlarına ise "KS" kodu verilmiştir ve ilk görüşme yapılan sosyal hizmet uzmanından başlanarak her birine "ES1, ES2; KS1, KS2"' şeklinde numaralar verilmiştir. 


\section{BULGULAR}

\subsection{Kadın Sosyal Hizmet Uzmanlarının Mesleki Sorunlarına İlişkin Yaklaşımı İle İlgili Bulgular}

Tablo 3: Kadın Sosyal Hizmet Uzmanlarının Çalışma Yaşamında Karşılaştıkları Sorunlarına İlişskin Dağılım

\begin{tabular}{|c|c|}
\hline Sorunlar & Frekans \\
\hline Mobbing & 13 \\
\hline Aşırı evrak yükü & 9 \\
\hline Mevzuattan kaynaklı sorunlar & 8 \\
\hline Maaşların yetersizliği & 7 \\
\hline İş yoğunluğu & 7 \\
\hline Kurumlardaki fiziki koşulların uygunsuzluğu & 7 \\
\hline Alınan kararlara yukarıdan müdahale edilmesi & 5 \\
\hline Kurumların hizmet içi eğitim sağlama yetersizliği & 5 \\
\hline Görev tanımında yer almayan işlerin verilmesi & 4 \\
\hline Sosyal hizmet uzmanlarına gerekli önem ve değerin verilmemesi & 4 \\
\hline İdareciler ile iletişim sorunları & 3 \\
\hline Koruyucu-önleyici ve toplumu geliştirici hizmetlerin yetersizliği & 3 \\
\hline Alan dışındaki meslek gruplarının bu mesleği icra etmeleri & 3 \\
\hline Bürokrasinin yavaşlı̆̆1 & 2 \\
\hline Can güvenliğinin olmaması & 2 \\
\hline İşe oranla çalışan yetersizliği & 2 \\
\hline Mesleki yetkinliğimizin önemsenmemesi & 2 \\
\hline Rotasyon olmamas1 & 2 \\
\hline Mesleki tükenmişlik, yıpranma & 1 \\
\hline Mesleğin yöneticiler tarafından tam olarak bilinmemesi & 1 \\
\hline Resmi kurumlar arasında iletişim kopukluğu & 1 \\
\hline Süpervizör sisteminin olmaması & 1 \\
\hline
\end{tabular}

Tablo 3 incelendiğinde, kadın sosyal hizmet uzmanlarının çalışma yaşamında en çok mobbing, aşırı evrak yükü, mevzuat kaynaklı sorunlar, maaşların yeterli olmaması, iş yoğunluğu, kurumlardaki fiziki koşulların uygun olmaması, alınan kararlara yukarıdan müdahale edilmesi, kurumların hizmet içi eğitim sağlama konusunda yetersiz oluşu sorunlarıyla karşılaştı̆g 1 görülmektedir. Bunu görev tanımında yer almayan işlerin verilmesi ve sosyal hizmet uzmanlarına gerekli önem ve değerin verilmemesi sorunları takip etmiştir. Frekansı en yüksek sorun olan mobbinge ilişkin kadın sosyal hizmet uzmanlarının üzerinde durdukları bazı görüşler şu şekildedir:

Sosyal hizmet müdahale sürecinde çeşitli baskılar nedeniyle yardıma ihtiyacı olmayan kişilere yardım bağlanmasina yönelik baskılanıyorum. Yani işleyiş ile ilgili nedenlerden dolay mobbing söz konusu. Ayrıca mobbing genellikle yöneticilerin davranış ve tavırlarından ve iş arkadaşlarımızın iş yapmamasından dolayı da olabiliyor (KS2). 
Çeşitli baskılar nedeniyle bazı vakalarda, yaptı̆̆ımız sosyal incelemelerimiz, mesleki sorumluluğumuz, mesleki değerlerimiz, etik ilkelerimiz, içimizdeki adalet sistemimiz ve insani karakterlerimiz hiçe sayllarak vakalarda ültimatom (emir) uygulandiğg zamanlar mobbinge uğruyorum. Kendime yönelik saygısızlık yapıldı̆̆ı düşüncesindeyim (KS4).

Daha çok sert tavırlarla karşılaşlyorum. 'Sen ne biliyorsun ki zaten' şeklinde itham ettikleri bile oldu. Özellikle söylenen sözler ve maruz kaldı̆̆ım mobbing beni çok incitiyor, motivasyonum düşüyor (KS14).

Deneyimi fazla olan meslek elemanlarını her şeyi biliyormuş havasinda olup kendini üstün görmesi ve üstten konuşması, 'sen deneyimsiz ve yenisin' şeklinde yaklaşılması. Bu üzerimde büyük bir baskl oluşturuyor ve hata yapmamallyım, göze batmamalıyım şeklinde bir düşüncenin oluşmasina sebep oluyor. Maruz kaldiğım mobbing bende yetersizlik hissi oluşturdu. Vakalara düzgün müdahale edebilecek miyim, noktasında tereddüt yaşadım. Acaba ben işi bilmiyor muyum, yanlı̧ mı yapıyorum diye, acaba haklılar mi, şeklinde kafamda sorulara sebep oldu ve özel hayatıma yansıdl, işten çıktı̆̆ımda hala düşünüyordum, aklımdan çıkmıyordu (KS17).

Görüldüğü gibi kadın sosyal hizmet uzmanları mesleki bağlamda ve kişilik bağlamında mesleki bilgi ve yeterliliklerini doğrudan sahaya aktarma noktasında kurumsal yönetim ve ekip içi ilişkilerde bariz bir şekilde sınırlandırılmaya maruz kalmaktadırlar. Bu durumun başka çalışmalarda da benzer şekilde olduğu görülmektedir. (Bkz: Yılmaz vd., 2008; DiPasquale, 2002).

Kadın sosyal hizmet uzmanlarının karşılaşmış olduğu diğer önemli bir sorun da aşırı evrak yükü ve iş yoğunluğu olarak görülmektedir. Aşırı evrak yükü ve iş yoğunluğuna ilişkin kadın sosyal hizmet uzmanlarının üzerinde durdukları bazı görüşler ise şu şekildedir:

Aşırl evrak yükü, yoğun talepler ve iş yoğunluğu nedeniyle her bireye gerektiği ölçüde hizmet sunulamiyor. Yetişemiyorum ve kendimi eksik görüyorum (KS10).

Tam anlamıyla sosyal hizmet yapıldiğını düşünmüyorum. Değişimi sağlamak için dezavantajl gruplara yönelik uzun süreli danışmanlık, rehberlik yapmak çok önemli. Fakat iş yükünün çok fazla olmasından mesleki çalışma için ayrllan süre daha az oluyor ve her birine uzun bir süre ayıramıyorsunuz. Kısacası iş yoğun, evrak yükü çok ve personel az olunca müracaatçlya ayırılan süre kısalıyor. Bu sebeple verimli çalıştı̆̆ımı hissedemiyorum (KS13).

Katılımcıların ifadeleri doğrultusunda, bireylere sundukları hizmetin etkili ve verimli olmasını engellediği için aşırı evrak yükü ve iş yoğunluğundan şikâyet ettikleri sonucuna varilabilmektedir.

Diğer bir sorun da kurumlardaki fiziki koşulların uygunsuzluğu olarak gündeme gelmektedir. Bu soruna yönelik bir katılımcı tarafından vurgulanan görüş ise şöyledir:

Müracaatçının gizliliğini koruma sosyal hizmetin temel ilkelerinden birisidir. Kurumların alt yapısının bu gizlilik ilkesine uyulabilmesi açısından müsait olmadiğı kanaatindeyim. İlçelerde bulunan Sosyal Hizmet Merkezleri gibi bazı kurumlar özellikle uygun değil. Özel görüssme odaları mevcut değil, sosyal hizmet uzmanlarl birden fazla kişinin bir arada bulunduğu odalarda görü̧̧üyor. Mesela müracaatçı yaşamış olduğu boşanma sürecini anlatıyor, böyle bir ortamda diğer iş arkadaşları da anlatılanlara şahit oluyor. Müracaatçıyla konuşurken diğer meslek elemanları ile görüşmek için başka bir müracaatçı da odaya giriyor ve o da şahit oluyor anlatılanlara (KS17). 
Görüldüğü gibi kadın sosyal hizmet uzmanları mesleki yaşamda en çok yönetici ve çalışma arkadaşlarından kaynaklı baskıya maruz kalmaktadırlar. Bu temel sorunun yanı sıra aşırı iş yükü, fiziksel koşulların yetersizliği, mesleği tam anlamıyla icra edememekten kaynaklanan yetersizlik duyguları gibi sorunlar dile getirilmektedir.

\subsection{Mesleki Sorunların Kadın Sosyal Hizmet Uzmanlarının Motivasyonuna Etkisine Dair Bulgular}

Araştırmada kadın sosyal hizmet uzmanlarının çalışma hayatında yaşadıkları sorunların motivasyonları üzerindeki etkilerinin neler olduğunun ortaya koyulması açısından da bir soru sorulmuştur. Katılımcılardan 14'ü iş hayatında yaşadıkları sorunların motivasyonlarını genellikle olumsuz yönde etkilediğini ifade etmiştir. Bu soruya verilen bazı cevaplar ise şu şekildedir:

Moral bozukluğu ve motivasyon düşüklüğü oluyor. İşimde göstermiş olduğum performans, buna bağlı olarak sağlanan verim azallyor, dikkatimin dağılmasına sebep oluyor ve mesleki anlamda tatmin olmamı engelliyor (KS7).

Motivasyonum düşüyor, psikolojim bozuluyor, bu çalışma performansımı etkiliyor, çalışasım gelmiyor ve işime kendimi veremiyorum, buna bağlı olarak işler aksıyor, tükenmiş hissediyorum (KS10).

Şevkim kırılıyor, meslekten soğuyorum, bıkkınlı̆ga sebep oluyor, yapılan hizmetlerde yetersizlik oluyor (KS9).

Zaman zaman ciddi yorgunluk oluşturmasına rağmen çalışma düzenimi etkilememektedir (KS13).

Sistem nitelikten çok niceliği ön plana çıkarmamı zorluyor. Müracaatçılar için doğru bilgi ediniliyor mu, etkili hizmet sunumu için yeterli süre veriliyor mu, hizmetten fayda sağlanıyor mu bakılmadan sayısal olarak kaç vakaya ile çalışıldı vb. ile ilgileniliyor. Sosyal hizmet müdahale sürecinde tanı koyma ve tedavi etmekten çok, kaç vakaya bakıldiğıyla ilgileniliyor. Bu durum çabuk tükenmişlik yaşayabileceğimden endişe etmeme sebep oluyor. Ayrıca iş yükümün ă̆ırl̆ğı ile baş etmeye çalışırken motivasyonum olumsuz etkileniyor (KS5).

Çözüm odaklı yaklaşmama rağmen motivasyonumu etkiliyor. Kendimi değersiz hissediyorum (KS6).

Katılımcıların ifadeleri çalışma yaşamında meydana gelen motivasyon düşüklügünün psikolojik etkilerinin yanı sıra iş performansına yönelik etkilerinin de olduğunu göstermektedir. Çalışma yaşamında meydana gelen motivasyon düşüklüğünün, sosyal hizmet uzmanlarının iş performansını olumsuz yönde etkilemesi üzerinde durulması gereken önemli bir konudur. Çünkü sosyal hizmet uzmanlarının faaliyette bulunduğu, toplumun dişına itilen, baskı ve ayrımcılıkla karşı karşıya kalan, suça sürüklenen, kendi kendine yetemeyen grupları, psikososyal yönden sağlıklı bireyler haline getirmek ve onları topluma kazandırmak, bu gruplara en çok fayda sağlayacak olan hizmeti sunmak, özverili bir şekilde çalışmayı gerektirir. Bu nedenle motivasyonlarının artırılmasına katkı sağlayacak kurumsal tedbirler almak gerekmektedir.

Erkek sosyal hizmet uzmanlarının da meslek hayatındaki sorunlara yaklaşımı benzerlikler göstermesine rağmen anlamlı farkl1lıklar da göstermektedir. 


\subsection{Erkek Sosyal Hizmet Uzmanlarının Mesleki Sorunlarına İlişkin Yaklaşımı İle İlgili Bulgular}

Tablo 4. Erkek Sosyal Hizmet Uzmanlarının Çalışma Yaşamında Karşılaştıkları Sorunlara İlişkin Dağılım

\begin{tabular}{|c|c|}
\hline Sorunlar & Frekans \\
\hline Mevzuattan kaynaklı sorunlar & 10 \\
\hline Sosyal hizmet uzmanlarına gerekli önemin ve değerin verilmemesi & 8 \\
\hline Koruyucu-önleyici ve toplumu geliştirici hizmetlerin yetersizliği & 6 \\
\hline Mobbing & 5 \\
\hline Kurumlardaki fiziki koşulların uygunsuzluğu & 5 \\
\hline Kurumların hizmet içi eğitim sağlama yetersizliği & 4 \\
\hline Alan dışındaki meslek gruplarının bu mesleği icra etmeleri & 4 \\
\hline Mesleğin yöneticiler tarafindan tam olarak bilinmemesi & 4 \\
\hline Mesleki tükenmişlik, yıpranma & 4 \\
\hline İş yoğunluğu & 4 \\
\hline Aşırı evrak yükü & 4 \\
\hline Maaşların yetersizliği & 4 \\
\hline Teorik bilgi ile uygulama arasındaki farklılıklar & 4 \\
\hline Alınan kararlara yukarıdan müdahale edilebilmesi & 3 \\
\hline İşe oranla çalışan yetersizliği & 3 \\
\hline Rotasyon olmaması & 2 \\
\hline Uygulamaya yönelik önerilerimizin dikkate alınmaması & 2 \\
\hline Can güvenliğinin olmaması & 2 \\
\hline Gerekli durumlarda hukuki yaptırımların yeterli olmaması & 2 \\
\hline İdealist meslek elemanı azlığ1 & 2 \\
\hline Mesleki yetkinliğimizin önemsenmemesi & 1 \\
\hline İdareciler ile iletişim sorunları & 1 \\
\hline Sosyal inceleme için her zaman araç bulamamak & 1 \\
\hline Resmi kurumlar arasında iletişim kopukluğu & 1 \\
\hline Bürokrasinin yavaşlı̆̆1 & 1 \\
\hline Süpervizör sisteminin olmaması & 1 \\
\hline
\end{tabular}

Tablo 4 incelendiğinde, erkek sosyal hizmet uzmanlarının çalışma yaşamında en çok mevzuattan kaynaklı sorunlar, sosyal hizmet uzmanlarına gerekli önemin ve değerin verilmemesi, koruyucu-önleyici ve toplumu geliştirici hizmetlerin yetersizliği, mobbing, kurumlardaki fiziki koşulların uygunsuzluğu sorunlarıyla karşılaştığı görülmektedir. Erkek sosyal hizmet uzmanlarının mevzuattan kaynaklı sorunlar üzerinde durdukları bazı görüşler şu şekildedir:

Niteliksiz politikalar üretilmesi. Niteliğin önemsenmesi yerine niceliğin önemsenmesi. Hizmette bulunurken belirlenen sayıya ulaşılmış mı ulaşılamamış mı ona bakılıyor. Bireylerde bir ilerleme kaydedilmiş mi, istenilen sonuç elde edilmiş mi bakllmıyor. Sunulan hizmetler gerçekten yeterli mi bakılmıyor (ES1). 
Mevzuat eksikliği nedeniyle sorunlar yaşıyorum. Mesleğimin bilinciyle bireylere profesyonel olarak yardım etmek istiyorum. Fakat mevzuatın gerektirdikleriyle vicdani ikilem arasında kaldı̆̆ım oluyor. Örneğin ă̆ır engelli olmayan aynı zaman da ailesinin de bakımını üstlenmediği bir kişi mevcut. Bu kişinin bakım merkezinden ücretsiz bir şekilde yararlanabilmesi için ağır engelli olması gerekiyor. Başka bir örnek, yaşlı bir birey bakım evine yerleştirilecek, gelir durumu, sağlık gibi bazı şartlara bakallyor. Yaşlının geliri çok az bir farkla belirtilen limitin üstündeyse hizmetten yararlanamiyor. Uygulanmak istenen sosyal hizmet müdahalelesi uygulanamiyor ve çözümsüz sorunlar meydana geliyor. Danışanlara hizmet ulaşamaması ve ihtiyaçlarının tam olarak karşılanmaması benim için büyük bir sorun oluşturuyor (ES4).

Etkili ve verimli hizmet sunulmasına engel olacak sosyal politika ve mevzuat eksiklikleri mevcut. Hükümlü ve tutukluların iyileştirilmesi ve topluma kazandırılmasına yönelik uygulamalar eksik ve dar bir çerçeve dahilinde, basitçe oluşturulmuş. Hükümlü ve tutuklulara sadece eğitim ve seminer veriyoruz. Bu yetersiz kaltyor, rehabilite edici çalışmalara ă̆ırlık verilmesi gerekiyor (ES14).

Mevzuattaki eksiklikler. Bu mesleki doyumun alınamamasına ve fayda sağlamıyorum düşüncesinin oluşmasına sebep oluyor. Mevzuatın bir yaptırımı ve bireyler üzerinde caydırıcı etkisi yok. Örneğin 6284 sayıl kadına karşı şiddetin önlenmesine dair olan kanuna göre şiddet gösteren eşe uzaklaştırma kararı veriliyor, fakat tekrar şiddet uygulayabiliyor eşine, çünkü herhangi bir yaptırımı yok. Yine 5395 sayılı kanuna göre sağlık, bakım, danışmanlık tedbiri veriliyor. Fakat danışmanlık tedbiri aldığımız müracaatçılar buna uymuyor (ES10).

Katılımcıların ifadeleri incelendiğinde erkek sosyal hizmet uzmanları, mevzuattan kaynaklı sorunlardan etkili ve verimli hizmet sunulmasını engellediği için şikayet etmektedirler.

Ortaya çıkan sonuçlara göre erkek katılımcılar, sosyal hizmet uzmanlarına meslek elemanı olarak gerekli önemin ve değerin verilmemesini de karşılaştıkları en önemli sorun olarak görmektedir. Sosyal hizmet uzmanlarına gerekli önemin ve değerin verilmemesine ilişkin erkek sosyal hizmet uzmanlarının üzerinde durdukları bazı görüşler ise şu şekildedir:

Mesleği herkesin yapabileceği yönünde oluşan algi ve her meslekten elemanın bu mesleği yapmast nedeniyle mesleğin dĕgersizleşmesi. Buna bağlı olarak biz sosyal hizmet uzmanlarına verilen değerin azalması sorunu mevcut (ES1).

Genel bir çerçeveden bakacak olursak, sosyal hizmet mesleği genellikle gerek yöneticiler olsun gerek toplum tarafindan olsun bilinmiyor. Sosyal yardim şartları sağlayanlara bağlanıyor ve bunu yapmak çalışan açısından nispeten kolay. Sosyal hizmetin de 'sosyal yardım' gibi kolaylıkla yapılabileceği algisı mevcut. Bu algı mesleğin herkes tarafindan yapılabileceği düşüncesini de beraberinde getiriyor ve ben bunun büyük bir sorun oluşturduğunu düşünüyorum. Mesleğin eğitimini aldığınızda olayları başka açılardan görebilme özelliği kazanıyorsunuz. Bizim yaptığımız meslekte, yani sosyal hizmet mesleğinde, etkili ve verimli bir müdahale ve uygulamada bulunulduğunda çıktılarının gerçekten çok daha fazla olduğunu görürsünüz. Sosyal hizmetin anlık çıktısı yok, ulaşılmak istenen sonucu almak uzun bir süreci gerektiriyor. Bunu göremedikleri için de mesleğin sosyal yardım bağlamak gibi kolay bir şekilde yapılabildiğine yönelik bir algı var. Bu durum da biz sosyal hizmet uzmanlarını değersizleştiriyor (ES16).

Genel olarak çok fazla emek sömürüsü mevcut. Özel sektörde özellikle asgari ücret ve bunun altı ücretlerle çalışanlar çok fazla. Ek ders karşıllı̆ çalışanların hiçbir özlük hakkı yok. En basitinden rehabilitasyon merkezlerinde yönetmelik değişikliği ile sosyal 
hizmet uzmanı çalıştırma zorunluluğu kalktı. Sosyal hizmet uzmanlarına gerek yokmuş gibi baklliyor (ES15).

Katılımcıların söylemleri incelendiğinde, erkek sosyal hizmet uzmanları genel olarak mesleğin kolaylıkla icra edilebilir olduğu ve sosyal hizmet uzmanlarına gerek olmadığı yönünde oluşan algılardan şikayet etmektedir. Katılımcılara göre koruyucu-önleyici ve toplumu geliştirici hizmetlerin yetersizliği de karşılaşılan bir diğer sorundur. Buna göre erkek sosyal hizmet uzmanlarının üzerinde durdukları bazı görüşler ise şu şekildedir:

Sosyal ekonomik destekteki, 'sosyal' olana önem verilmiyor, yalnızca 'ekonomik' kısmı ön plana çıkıyor. Ekonomik desteğe önem verilmesi sosyal hizmetin 'sosyal yardım' mesleği gibi algllanmasına sebep oluyor. Bireyleri ve toplumu gelişstirici, sağllklı değişim sağlayıcı hizmetlerin artırılması gerekmektedir (ES10).

Hizmet sunumunda kriz odaklı çalışıldı̆̆g, yani problem meydana geldikten sonra harekete geçildiği için mesleki gerekliliklerin tam anlamıyla yerine getirilmediğini düşünüyorum. Olması gereken koruyucu-önleyici çalışmalara daha fazla önem verilmesi ve politikaların bu yönde gelişmesidir (ES2). ise şöyledir:

Kurumlardaki fiziki koşulların uygunsuzluğu sorununa yönelik ortaya konulan bir görüş

Bakım merkezlerine acil yerleștirilmesi gereken bireyler var. Hizmetten yararlanabilmek için müracaatçı uzun süre sıra bekliyor. Bakım merkezi, huzurevi eksikliği çok fazla. Huzurevi sayısının artıılması gerekiyor. Ayrıca çağımıza uygun hizmetler gelişmiyor. Gündüzlü bakımevi gibi günümüzün şartlarına uygun kuruluşlar yok denecek kadar az. Biz alanin içinde olduğumuz için neyin eksik olduğunu görebiliyoruz. Önerilerimiz var, fakat önerilerimiz dikkate alınmıyor (ES4).

Görüldüğü gibi erkek sosyal hizmet uzmanları meslek hayatında mevzuattan kaynaklı, meslek elemanı olarak gerekli değeri görmeme, koruyucu-önleyici hizmetlerin yetersizliği gibi sorunları öncelikli olarak dile getirmektedirler. Sosyal hizmet eğitiminin özellikle 2000'li yıllardan sonra yaygınlaşmasıyla sosyal hizmet uzmanları daha yoğun olarak sahada çalışmaktadırlar. Nispeten mesleğin Türkiye'de yeni olmasından kaynaklı yasal ve hukuki boşluklar en çok sosyal hizmet uzmanlarını etkilemektedir. Bu nedenle Türkiye'de bu tür sorunların çözümü sosyal hizmet uzmanlarının mesleki sınırlarını da belirginleştirecek, böylece sosyal hizmet uzmanlarının yasal görevini bir başka meslek elemanı yüklenmeyecektir.

\subsection{Mesleki Sorunların Erkek Sosyal Hizmet Uzmanlarının Motivasyonuna Etkisine Dair Bulgular}

Araştırmada erkek sosyal hizmet uzmanlarının çalışma hayatında yaşadıkları sorunların motivasyonları üzerindeki etkilerinin neler olduğunun ortaya koyulması açısından da bir soru sorulmuştur. Katılımcılardan 13'ü iş hayatında yaşadıkları sorunların motivasyonlarını genellikle olumsuz yönde etkilediğini ifade etmiştir. Bu soruya verilen bazı cevaplar ise şu şekildedir:

Yıpranıyorum. Kaygı, yetersizlik, stres yaşıyorum. Sabrım tükeniyor, tükenmişlik yaşıyorum. 'Başka bir mesleği yapmak istiyorum.' dediğim çok oldu (ES4).

Zorlu bir meslek yaparken, böylesine sorunlar yaşadiğımda tükenmişliğe daha çok yaklaşıyorum. Enerjim düş̧üğü için gerekli özeni gösteremiyorum. Bu da verim alınmasinı engelliyor. Vaka ile daha iyi ilgilenebilecek potansiyelim var fakat bu potansiyeli gösteremiyorum (ES6). 
Yllgınlık ve değersizlik duygularl ve enerji düşüklüğ̈̈ oluyor. Zaman zaman çaresizlik hissi yaşıyorum, bocallyorum. Verimli olamıyorum (ES7).

Mesleğe başladığım ilk zamanlardaki ideallerimden uzaklaştım. Bu da kendimi geliştirme isteğimi engelledi (ES12).

Sorunlar motivasyonumu kötü etkiliyor. Gün içerisinde motivasyon düzeyime 0 ile 10 arasında bir değer versem 4 verirdim (ES2).

Katılımcıların ifadeleri çalışma yaşamında meydana gelen motivasyon düşüklüğünün psikolojik etkilerinin oldukça fazla olduğunu göstermektedir. Sosyal hizmet uzmanları, gün içerisinde çok çeşitli ve karmaşık vakalarla karşı karşıya kalırlar ve bu vakalarda, müracaatçıya uygun bir hizmet modeli geliştirerek müracaatçılarının tüm hayatını etkileyebilecek bir karar alabilirler. Böylesine bir sorumluluğu almayı gerektiren, zorlu ve stresli bir mesleği icra ederken çalışma hayatında karşılaşılan sorunlar, sosyal hizmet uzmanlarını daha fazla etkilemekte ve motivasyon düşüklüğü, yıpranma, stres, tükenmişlik gibi semptomlara yol açmaktadır. $\mathrm{Bu}$ nedenle kurumsal düzlemde sosyal hizmet uzmanları için motivasyon artırıcı tedbirler alınmalıdır.

\section{TARTIŞMA}

$\mathrm{Bu}$ araştırmada, sosyal hizmet uzmanlarının iş yaşamlarında karşılaştıkları sorunlar incelenmiştir. Bu bağlamda, kadın sosyal hizmet uzmanlarının çalışma yaşamında en çok karşılaştıkları sorunun mobbing davranışına maruz kalmak olduğu belirlenmiştir. Özmete ve Laleoğlu'nun (2013: 32) da sosyal hizmet uzmanlarının karşılaştıkları mobbing davranışları ile ilgili yapmış oldukları araştırmasında, sosyal hizmet uzmanlarının çoğunlukla iş arkadaşlarının arkalarından konuştuklarını, dedikodu yaptıklarını ve çalışırken kendilerini kaygılı hissettiklerini belirttikleri ortaya çıkmıştır. Mobbinge maruz kalmanın birey üzerinde fiziksel ve psikolojik olmak üzere pek çok etkisinin olduğu ve bu durumun iş performansını da olumsuz etkilediği düşünüldüğünde kurumlarda mobbingin önlenmesi oldukça önemlidir. Kadın sosyal hizmet uzmanlarının en çok karşılaştıkları bir diğer sorun aşırı evrak yüküdür. Calitz ve diğerleri (2014) de yapmış oldukları çalışmada, sosyal hizmet uzmanlarının fazla iş yükü nedeniyle iş stresi ve tükenmişlik yaşadıkları, bunun sonucu olarak kendilerini duygusal olarak bitkin ve verimsiz hissetmeye eğilimli olduklarını belirtmiş̧lerdir (Aktaran; Uğur ve Erol: 2015: 989). Aynı şekilde, Hablemitoğlu ve Özmete'nin (2012: 189) yapmış olduğu çalışmada sosyal hizmet uzmanlarının çok sayıda vaka ile karşılaştığı ve \%94,3' ü için en önemli stres kaynağının iş yükünün fazla olması olduğu ortaya konulmuştur. Son olarak, Ceylan, Gül ve Öksüz (2016: 65) de yapmış oldukları çalışmada, aşırı evrak yükünün, tıbbi ve adli sosyal hizmet alanlarının dışındaki diğer alanlarda çalışan sosyal hizmet uzmanlarının, iş doyumunu düşüren ve tükenmişlik yaşamalarına yol açan faktörlerden biri olduğunu belirlemişlerdir.

Kadın sosyal hizmet uzmanlarının bu sorunlarını, mevzuattan kaynaklı sorunlar, maaşların yeterli olmaması, iş yoğunluğu, kurumlardaki fiziki koşulların uygun olmaması, alınan kararlara yukarıdan müdahale edilmesi, kurumların hizmet içi eğitim sağlama konusunda yetersiz oluşu sorunları takip etmiştir. Güzel ve Selçuk'un (2017: 2857) Rize ilinde yapmış oldukları çalışmasında da araştırmaya katılan tüm sosyal hizmet uzmanları kurumun fiziki şartlarının ve çalışma ortamının, bulundukları odada çok kalabalık olmaları ve yalnızca bir adet görüşme odasının bulunması gibi nedenlerden dolayı elverişsiz olduğunu belirtmişlerdir. Katılımcılara göre bu durum müracaatçı ile yapılacak bir görüşmeyi pek çok defa bölmekte ve vakaya yoğunlaşmayı engellemektedir. Yapılan görüşmenin bölünmesi ve vakaya yoğunlaşamamak hem müracaatçının sürece dahil olmasını hem de sosyal hizmet uzmanının müracaatçıyı etkin bir şekilde dinlemesini zorlaştıracak, buna bağlı olarak sosyal hizmet uzmanının mevcut sorundaki ayrıntıları kaçırması ve yanlış kararlar alması ihtimali meydana 
gelecektir. Diğer yandan araştırmacılar aynı çalışmada, katılımcıların hepsinin aldıkları ücretlerin yetersiz olduğunu, bu durumun da yaşam şartlarını ve iş motivasyonlarını etkilediğini ifade ettikleri sonucunu elde etmişlerdir.

Yapılan bu çalışmada erkek sosyal hizmet uzmanlarının ise çalışma yaşamında en çok mevzuattan kaynaklı sorunlarla karşılaştı̆̆ı belirlenmiştir. Çünkü sosyal hizmet uzmanları, müracaatçılara ihtiyacı olan hizmeti sunarken mevzuatlara ve bazı prosedürlere bağlı kalmaktadırlar. Mevzuatlar, bazı vakalarda müracaatçıların problemlerine çözüm üretme noktasında yetersiz kalmaktadır. Böylesine vakalarda alternatif bir çözüm yönteminin olmaması, müracaatçıya faydalı bir hizmet sunumunu engellemekte, bu da sosyal hizmet uzmanları için sorun teşkil etmektedir. Çünkü sosyal hizmet uzmanları müracaatçılarına fayda sağlamak için çabalayan meslek elemanlarıdır. Nitekim yapılan araştırmalar müracaatçılarının sorunlarını çözememenin sosyal hizmet uzmanlarının yüksek düzeyde stres yaşamasına sebep olan faktörlerden birisi olduğunu belirlemiştir (Uğur ve Erol, 2015). Bu bağlamda kadın sosyal hizmet uzmanları çalışma yaşamında en çok karşılaştıkları sorunun mobbinge maruz kalmak olduğunu ifade ederken erkek sosyal hizmet uzmanları mevzuattan kaynaklı sorunlardan şikâyet etmişlerdir. Kadın sosyal hizmet uzmanlarının mobbing davranışlarından daha fazla şikayetçi olmalarının nedeni, çalışma hayatında kadınların, erkeklere göre daha zayıf olduğuna dair oluşan genel kanı nedeniyle kadınların üzerinde daha fazla baskı oluşması ve iş ilişkilerinden kaynaklanan problemlerin kadınlar için erkeklere oranla daha fazla duygusal etki yaratması olabilir. Diğer yandan erkek sosyal hizmet uzmanlarının mevzuattan kaynaklı sorunlardan daha fazla şikayetçi olmalarının nedeni, her alanın mevzuatı farklı olduğu için kadın katılımcılarla erkek katılımcıların çalıştığı sosyal hizmet alanının farklılaşması olabilir.

Erkek sosyal hizmet uzmanlarının bu sorununu, sosyal hizmet uzmanlarına gerekli önemin ve değerin verilmemesi, koruyucu-önleyici ve toplumu geliştirici hizmetlerin yetersizliği, mobbing, kurumlardaki fiziki koşulların uygunsuzluğu sorunları takip etmiştir. Benzer olarak Berkün (2010: 106)'ün araştırmasında Bursa Aile ve Sosyal Politikalar İl Müdürlügü bünyesinde ve bu müdürlüğe bağlı kuruluşlarda çalışan sosyal hizmet uzmanlarının çalışma hayatındaki mesleki sorunlarının neler olduğu belirlenmiştir. Buna göre sosyal hizmet uzmanları hizmet içi eğitim programlarının az olduğunu, çalıșma ortamının fiziksel donanım, araç-gereç yönünden eksik olduğunu ifade etmişlerdir. Kurum yöneticileri ise daha etkin ve verimli sosyal hizmet faaliyetlerinin sunulması için yasal ve yönetsel düzenlemelere ihtiyaç duyduklarını belirtmişlerdir. Görüldüğü gibi yapılan bu çalışma, diğer çalışmaların sonuçları ile benzerlik göstermekte, bu da araştırmanın sonuçlarını desteklemekte ve güçlendirmektedir.

\section{SONUÇ}

$\mathrm{Bu}$ araştırmada, sosyal hizmet uzmanlarının iş yaşamlarında karşılaştıkları sorunların neler olduğu incelenmiştir. Kadın sosyal hizmet uzmanlarının çalışma yaşamında en çok karşılaştıkları sorunlar mobbing davranışına maruz kalmak, aşırı evrak yükü, mevzuattan kaynaklı sorunlar, maaşların yeterli olmaması, iş yoğunluğu, kurumlardaki fiziki koşulların uygun olmaması, alınan kararlara yukarıdan müdahale edilmesi, kurumların hizmet içi eğitim sağlama konusunda yetersiz oluşu olarak belirlenmiştir. Erkek sosyal hizmet uzmanlarının ise çalışma yaşamında en çok mevzuattan kaynaklı sorunlar, sosyal hizmet uzmanlarına gerekli önemin ve değerin verilmemesi, koruyucu-önleyici ve toplumu geliştirici hizmetlerin yetersizliği, mobbing, kurumlardaki fiziki koşulların uygunsuzluğu sorunları ile karşılaştı̆̆ belirlenmiştir. Elde edilen sonuçlar karşılaştırıldığında kadın sosyal hizmet uzmanlarının çalışma yaşamında en çok karşılaştığı sorunun mobbing davranışına maruz kalmak olduğu, erkek sosyal hizmet uzmanlarının ise etkili ve verimli hizmet sunulmasını engellediği için mevzuattan kaynaklı sorunlar olduğu görülmüştür. 
Araştırmada kadın sosyal hizmet uzmanlarının büyük çoğunluğunun çalışma hayatında karşılaştığı sorunların motivasyon düzeylerini olumsuz yönde etkilediği ve bu motivasyon düşüklüğünün tükenmişlik, bıkkınlık, mesleki tatminsizlik gibi psikolojik etkileri ile birlikte iş performansına yönelik olumsuz etkilerinin olduğu belirlenmiştir. Benzer şekilde erkek sosyal hizmet uzmanlarının büyük çoğunluğunun da çalışma hayatında karşılaştığ sorunların motivasyon düzeylerini olumsuz yönde etkilediği ve bu motivasyon düşüklüğünün tükenmişlik, yıpranma, kaygi, yetersizlik, değersizlik, enerji düşüklüğü gibi psikolojik etkilerinin olduğu belirlenmiştir. Motivasyon düşüklüğünün sosyal hizmet uzmanlarının hem kendileri üzerinde hem de iş performansları üzerinde olumsuz etki oluşturması üzerinde durulması gereken önemli bir konudur. Çünkü dezavantajlı gruplarla çalışılan ve bu grupların psikososyal iyilik halinin sağlanması, topluma kazandırılması gibi önemli görevler üstlenilen sosyal hizmet mesleğinde, hedeflenen sonucun alınabilmesi son derece önemlidir. Bu bağlamda sosyal politika üreticilerinin, ulusal ve uluslararası boyutlarda etkin olan sosyal hizmet kurum ve kuruluşlarının araştırmada belirlenen sorunlara çözüm üretebilme noktasında çalışma ve uygulama yapmaları gerekmektedir.

Benzer araştırmaların sayısının artması, sosyal hizmet uzmanlarının sorunlarının azaltılabilmesi için odaklanılması gereken unsurları belirginleştirecektir. Bu nedenle, bu konuya ilgi duyan başka araştırmacılara, konuya dair elde edilen bilgilerin çeşitlenmesi ve derinleşmesi için özel sektör, sivil toplum kuruluşları ve gönüllü kuruluşların yer aldığı, sosyal hizmet uzmanlarının da bu kuruluşlarda aktif olarak çalıştığı farklı illerde ve daha geniş örneklemle çalışmalar yapmaları gerekmektedir.

\section{Araştırma ve Yayın Etiği Beyanı}

Bu çalışma bilimsel araştırma ve yayın etiği kurallarına uygun olarak hazırlanmıştır. Çalışmanın türetildiği yüksek lisans çalışması kapsamında Uşak Üniversitesi Sosyal ve Beşerî Bilimler Araştırma ve Yayın Etiği Kurulundan 10.01.2019 tarihinde alınan Etik Kurul Onay belgesi sunulmuştur.

\section{Yazarların Makaleye Katkı Oranları}

Birinci yazarın makaleye katkıs1 \%50, İkinci yazarın makaleye katkısı \%50'dir.

\section{Çıkar Beyanı}

Yazarlar açısından ya da üçüncü taraflar açısından çalışmadan kaynaklı çıkar çatışması bulunmamaktadır.

\section{KAYNAKÇA}

Alptekin, K. (2016). Başlangıçtan bugüne ve yarına Türkiye'de sosyal hizmet eğitimi. Ankara: Nobel Akademik Yayınc1lik.

Augustine, M. G. \& Gentle Genitty, C. (2013). A perspective on the historical epistemology of social work education, R. Bakos Block (Eds.), Perspectives on social work (pp. 9-21). Houston: The Journal of the Doctoral Students of the University.

Berkün, S. (2010). Sosyal hizmet uzmanlarının çalışma hayatında karşılaştıkları mesleki sorunlar: Bursa örneği. Toplum ve Sosyal Hizmet, 1, 99-109.

Ceylan, H. Gül, N. ve Öksüz, M. (2016). Sosyal çalışmacılarda iş doyumu ve tükenmişliğe etki eden faktörlerin sosyal hizmet alanlarına göre karşılaştırmalı incelenmesi. Yalova Sosyal Bilimler Dergisi, 6(11), 44-69.

Di Pasquale, V. (2002). Study examines mobbing at the workplace. https://www.eurofound.europa.eu/publications/article/2002/study-examines mobbing-at-the-workplace adresinden alınmıştır.

Doel, M. (2012). Social work the basics. Londra: Routledge.

Duyan, V. (2019). Sosyal hizmet temelleri, yaklaşımları, müdahale yöntemleri. Ankara: Nar Yayınları. 
Engelbrecht, L.K. (1999). Introduction to social work. Wellington: Lanzo Yayınc1lık.

Güzel, B. ve Selçuk, O. (2017). Sosyal çalışmacıların karşılaştıkları zorluklar ve başa çıkma yolları: Rize örneği. Journal of Human Sciences, 14(3), 2848-2864.

Hablemitoğlu, Ş. ve Özmete, E. (2012). Sosyal çalışmacıların iş yaşamı kalitesi: Şefkat yorgunluğu, tükenmişlik, stres kaynakları, iş tatmini ve kariyer olanakları. Ankara Sağllk Bilimleri Dergisi, 1, 171-213.

Hokenstad, T. (2012). Social work education: The international dimension, K. Lyons, T. Hokenstad, M. Pawar, N. Huegler \& N. Hall (Eds.), The sage handbook of international social work (pp. 163-178). London: Sage Publications.

Humphrey, C. (2011). Becoming a social worker. India: SAGE Publications.

Işıkhan, V., Erbay, E., Akçay, S. ve Ege, A. (2016). Sosyal hizmet bölümü öğrencilerinin mezuniyet sonrası gelecek planları: Ankara, Başkent ve Hacettepe Üniversitesi örnekleri. Toplum ve Sosyal Hizmet Dergisi. 1, 7-24.

Koç, S.Ç. (2015). Sosyal hizmet uzmanlarının sorun çözme becerileri üzerine bir araştırma. Yüksek Lisans Tezi, Hacettepe Üniversitesi, Ankara.

Kongar, E. (1972). Sosyal çalışmaya giriş. Ankara: Şafak Matbaası.

Kut, S. (1988). Sosyal hizmet mesleği nitelikleri, temel unsurlarl, müdahale yöntemleri. Ankara

Özmete, E. ve Laleoğlu, A. (2013). İnsani hizmet örgütlerinde sosyal çalışmacıların karşılaştıkları mobbing davranışları ile iş tatmini ve sağlık sorunları arasındaki ilişkinin değerlendirilmesi. Toplum ve Sosyal Hizmet Dergisi, 2, 23-44.

Payne, M. (2008). Complexity and social work theory and practice. Social Work Now Dergisi, 15-20.

Sheafor, B. W. ve Horejsi, C. J. (2014). Sosyal hizmet uygulaması: Temel teknikler ve ilkeler. (Çev. Yıldırım, B. \& Hatiboğlu Eren, B. \& Öngen, Ç. \& Beydili, E. \&Erükçü Akbaş, G. \& Adıgüzel, İ.B. \& Akçay, S. \& Özateş Gelmez, Ö, S). Nika Yayıncılık. (Orijinal çalışmanın yayın tarihi 2009)

Thompson, N. (2013). Kuram ve uygulamada sosyal hizmeti anlamak. (Çev. Bilgen, A. \& Kaynarkaya, B. \& Gülmez, D. \& Baran Çiftci, D. \& Türközü, S. E. \& Çoban, F. \& Çelik, G. \& Özen, H. \& Uraz, O. \& Uraz, T. \& Oğuz, Y.S). Dipnot Yayıncılık. (Orijinal çalışmanın yayın tarihi 2012)

Uğur, A. ve Erol, Z. (2015). Sosyal çalışmacıların çalışma hayatında karşılaştıkları stres faktörlerine yönelik kavramsal bir değerlendirme ve stres yönetimi müdahale programları. Uluslararası Sosyal Araştırmalar Dergisi, 39, 987-997.

Yılmaz, A. Ergun Özler, D. ve Mercan, N. (2008). Mobbing ve örgüt iklimi ile ilişkisine yönelik ampirik bir araştırma. Elektronik Sosyal Bilimler Dergisi. 7, 334-357.

Yiğit, T. (2017). Türkiye'de sosyal hizmet eğitim/öğretiminde kalite güvence sistemi ve akreditasyon standartlarına ilişkin bir model çerçeve önerisi. Toplum ve Sosyal Hizmet Dergisi. 1, 151-168.

Zastrow, C. (2016). Sosyal hizmete giriş. Ankara: Nika Yayıncılık. 


\section{Extended Summary}

\section{Problems of Social Workers Encountered in Working Lives: Example of Burdur Province}

Social work is a professional study that includes assistance to individuals, groups, families and communities to increase social functionality, to increase the capacity of people to solve problems, to cope and develop, to ensure that the systems function effectively and humanly, to create social conditions suitable for the goals that are missed (Zastrow, 2016). In order for a job to be defined as a profession, some elements are required. These elements are purpose, method, knowledge base, education, application area and staff of practitioners, professional values and acceptance of the society (Kongar, 1972). What makes social service a profession is the practitioners of the work, social workers. In this context, it will be appropriate to touch on the concept of social worker in order to understand the issue better.

Social workers are professionals who work on humans who fail to solve their problems on their own and humanitarian situations with the acceptance that human is an important and valuable asset. These people are in the situation of being disabled, poor, convicted, neglected or abused etc. Working with individuals in this situation requires a specific education that includes methods and techniques specific to the social work profession. In this context, social workers are people who are equipped with knowledge, values and skills in order to work in consideration of the disadvantaged people and their interaction with their environment. However, as in every profession, there are some problems in the social work profession and some factors that prevent the practice of the profession at the highest level of efficiency. The fact that individuals do not have much knowledge about who social workers are and what they do shows that the image of the profession is low on society basis, which can reduce social workers' commitment to the profession. On the other hand, some social workers complain about the increasingly procedural nature of their work and that they cannot spare as much time for protective and preventive work as they want. Some studies have shown that social workers are gradually detaching from the professional services they provide and drowning in routine processes and professionalism in the job has been replaced by bureaucracy (Thompson, 2013: 237). In addition, due to the fact that time is limited, other problems that social workers face in their professional lives are making decisions without going down to the source of the problems of the individuals, not having enough interviews, too much administrative control in professional interventions, excessive workload, and gender-based problems. There are a lot of issues to be clarified in addition to these for social workers in Turkey.

In this respect, defining the problems of a profession which can be considered still young in Turkey will make significant contributions to the social functionality of the profession. Therefore, in this study, the problems experienced from the perspective of social workers have been tried to be evaluated. For this purpose, what are the problems expressed by female social workers working in any field of the social work profession? (1) What are the problems expressed by male social workers working in any field of social work profession? (2) What are the effects of the problems experienced in working life on the motivation of social workers? (3) answers to questions were sought. On the other hand, research is a case study at the qualitative research level. The data obtained were analyzed descriptively by subjecting them to content analysis through inductive analysis. In this study, it has been aimed to analyze the problems that social workers face in their working lives. In this context, this research is a case study at the qualitative research level. Within the scope of the research, all social workers in Burdur province and its districts were reached and 33 social workers were interviewed. In the research, a semi-structured interview form was created and the individual interview technique, which is the data collection method of qualitative research, was used. The data obtained were subjected to content analysis 
through inductive analysis and descriptively analyzed, and NVIVO package program was used for analysis.

As a result of the research, it has been determined that the most common problem faced by female social workers in working life is exposure to mobbing behavior. This was followed by problems such as excessive paperwork, legislation-related problems, insufficient wages, work intensity, inadequate physical conditions in institutions, inadequate intervention in decisions, and in-service training. Male social workers, on the other hand, were found to encounter problems arising from the legislation mostly in their working life. This was followed by the problems of not giving the necessary importance and value to social workers, insufficient protective and preventive services, mobbing, and inconvenience of physical conditions in institutions. When the results obtained were compared, it was observed that the most common problem faced by female social workers in working life was exposure to mobbing behavior, for men, there were legislative problems because of the fact that male social workers prevented the provision of effective and efficient service. Again, in the study, it was determined that the problems faced by the majority of female social workers in work life negatively affect their motivation levels, and this low motivation has negative effects on job performance along with psychological effects such as burnout, boredom, and professional dissatisfaction. Similarly, it has been determined that the majority of male social workers were affected in terms of motivation levels problems faced in working life and this low motivation has psychological effects such as burnout, worn-out, anxiety, inadequacy, unworthiness, and low energy. 